\title{
56. MECHANISM OF SILL INTRUSION INTO SOFT SEDIMENT AND EXPULSION OF PORE WATER ${ }^{1}$
}

\author{
Gerhard Einsele, Geologisches Institut der Universität Tübingen, \\ 7400 Tübingen 1, Sigwartstrasse 10, Federal Republic of Germany
}

\begin{abstract}
In the active spreading center of the Guaymas Basin, several Leg 64 holes struck basaltic sills intercalated with very young, soft, and still partially hot sediment. This discovery and the measurement of mass physical properties provided a unique opportunity to study the mechanism of sill intrusion in statu nascendi. From a mechanical point of view, it can be shown that, in general, the upwelling magma must form sills as soon as it reaches soft sediment. The vertical buildup of an alternating sill-sediment sequence is controlled by the thickness of the sill contact, the interval (and volume) of magmatic pulses, and the sedimentation rate. Sill intrusions are formed continuously, so long as sediment accumulation is at least as rapid as vertical buildup by sills-including their upper contact zone. Lateral building of oceanic crust by dikes must be much faster, however, because the spreading rate exceeds the accumulation rate by a factor of 30 to 60 . As many as several tens of meters below and above the sills, all mass physical properties of the sediment are substantially changed by the sill load, by dissolution of opaline silica and by partial dissolution of carbonate, and possibly by shrinkage in conjunction with a steam zone that occurred at an early stage of the intrusion. From the reduction of porosity at the contact of the uppermost sill, height of expelled pore water is about 30 meters. Thus, space is created for the intruding magma, and the huge amounts of escaping pore water create a hydrothermal system, precipitating part of their dissolved constituents on the seafloor.
\end{abstract}

\section{INTRODUCTION}

On Leg 64, holes were drilled at three sites in the Guaymas Basin to explore the sediment and crustal growth in a gulf-type spreading center (see Introduction, this volume, Pt. 1). At all three sites $(477,478$, 481 ), basaltic sills were encountered below or between soft sediment at shallow burial depths. ${ }^{2}$

This study examines the mechanics of the emplacement of basaltic dikes and sills in highly porous sediment on the seafloor. To my knowledge, this has yet to be done: In similar situations in young, narrow, ocean basins (e.g., the Red Sea and the Gulf of Aden), it was not feasible to drill into basalts below the sediment on top of active spreading axes (see Whitmarsh et al., 1974; Fisher et al., 1974). There are some important studies on the consequences of basaltic intrusions into ancient sediment on land (e.g., Grapes et al., 1974; Sauvan et al., 1975; Frankel 1967). But in all these cases, the sediment and magmatic rocks were strongly affected later by the overburden pressure of overlying deposits and often by faulting, folding, early and late diagenesis, and even metamorphism. Thus, in previous studies it was difficult or impossible to reconstruct the original emplacement and the primary effects of basaltic intrusions on neighboring sediment. In the Guaymas Basin, the formation of new oceanic crust by emplacement of dikes and sills in soft sediment is still in progress. One of the sills was still hot (see site chapter, Site 477, this volume, Pt. 1), and unusually high heat-flow values were mea-

\footnotetext{
${ }^{1}$ Curray, J. R., Moore, D. G., et al., Init. Repts. DSDP, 64: Washington (U.S. Govt. Printing Office)

2 For the first report on the consequences of these intrusions for the neighboring sediment and their organic chemistry and the expulsion of pore water and its dissolved constituents, see Einsele et al., 1980
}

sured at all sites. Determining mass physical properties of sediment and basaltic rocks (see site chapters this volume, Pt. 1 and Einsele, this volume, Pt. 2) provides a realistic evaluation of different burial depths and an estimate of the amount of pore water expelled from the sediment by heat and additional overburden pressure.

\section{EMPLACEMENT OF SILLS IN SOFT SEDIMENTS}

According to Williams and McBirney (1979), the ability of magma to rise through the lithosphere is usually explained in terms of the depth and density relations of the magma and the surrounding rocks. The pressure of magma at its source is controlled by the lithostatic load of overlying rocks, and the maximum level the magma can rise depends on the density of the magma. At midoceanic ridges, the basaltic magma is usually raised to about 2500 meters below sea level (Sclater et al., 1971). After reaching the seafloor, it flows laterally to form the well-known lava beds. Only locally, where unusually large amounts of magma are extruded and the pressure is sufficiently high, can it form seamounts or volcanic islands.

In the spreading centers of the Gulf of California, the pressure and volume of magma are usually insufficient to raise the magma (excluding young volcanic submarine knolls or islands that protrude from the seafloor) higher than 2000 to $\mathbf{3 0 0 0}$ meters below sea level. Unlike mid-oceanic ridges, the rising magma tends to reach the seafloor at its deepest depressions. But before it ascends to the seafloor, it is forced, by its hydrostatic pressure, into soft sediment deposited at an accumulation rate of at least $1 \mathrm{~km} / \mathrm{m} . \mathrm{y}$. just in these depressions (Fig. 1).

This process can be described and explained in the following way: Prior to a new pulse of spreading and intrusion of magma, we assume a sedimentary sequence 
A

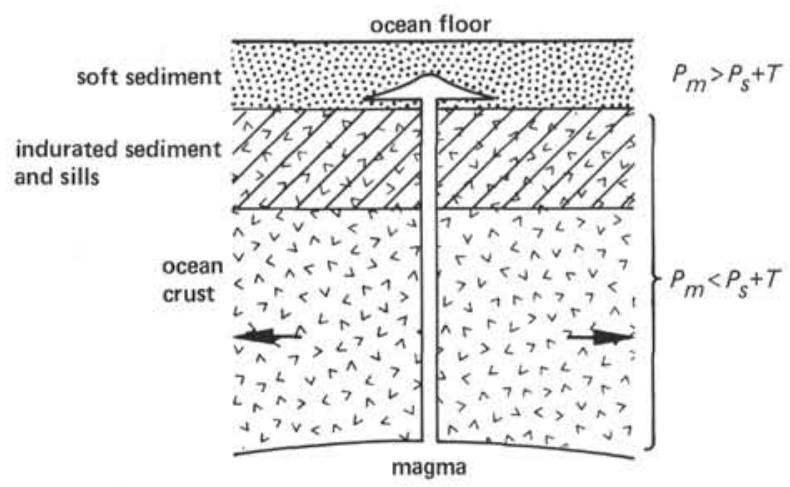

B

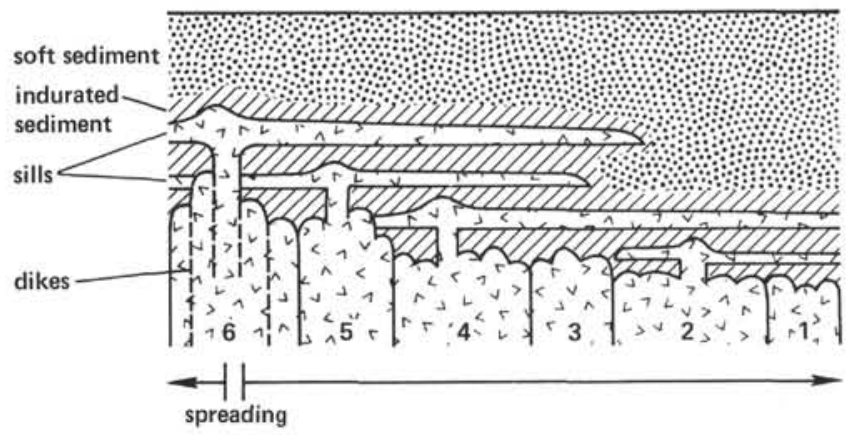

Figure 1. Exceptionally simplified and idealized models of the emplacement of basaltic sills in soft sediments. A. Single feeding conduit (tensional fissure) caused by spreading. Sill intrusion occurs where magma pressure, $P_{m}$, is greater than lithostatic pressure, $P_{s}$, of neighboring rocks or sediment plus their tensile strength, $T$. B. Horizontal and vertical sequence of basaltic dikes and sills intercalated with soft and sill-influenced indurated sediment. Numbers signify succession of events.

with mass physical properties as shown in Figure 2A. The depth relation of wet-bulk density to vane shear strength shown here is characteristic of clayey diatomaceous ooze at all drilling sites in the Guaymas Basin (see Einsele, this volume, Pt. 2). Induration may start abruptly at 200 meters sub-bottom; then, bulk density increases to values of about $2.0 \mathrm{~g} / \mathrm{cm}^{3}$, and undrained shear strength or cohesion $S_{u}$ becomes very high (we assume that it starts with $0.5 \mathrm{MPa}$ and increases rapidly to $2 \mathrm{MPa}$ at 300 meters sub-bottom). The vertical effective overburden pressure $P_{s}$ exerted by the sediment load (minus buoyancy) is plotted versus depth in Figure 2B. It is this lithostatic pressure that the magma must overcome before it can penetrate the sediment. For the very soft sediment of the Guaymas Basin, we assume that the vertical and horizontal components of this lithostatic pressure are equal, i.e., that we have hydrostatic conditions. (The hydrostatic pressure of the overlying seawater need not be considered here and in the following discussion.) But the tensile strength $T$ of the sediment also resists magmatic intrusions. If the undrained vane shear strength $S_{u}$ measured on shipboard (see Einsele, this volume, Pt. 2) were regarded as the in situ strength and were made equal to the tensile strength $T$ (which, though not quite accurate, is sufficient for this study), we would obtain a relation $P_{s}+T$ versus depth (Fig.
2B). The hydrostatic pressure of the magma must exceed $P_{S}+T$ for an intrusion to occur (see also Bradley, 1965; Roberts, 1970).

Below the sea, buoyancy reduces the bulk density of rising magma as it does that of the sediment. Williams and McBirney (1979) assumed it to be $1.7 \mathrm{~g} / \mathrm{cm}^{3}$ (buoyant bulk densities of basaltic rocks from Sites 477,478 , and 481 were $1.66-1.89 \mathrm{~g} / \mathrm{cm}^{3}$; mean value about 1.80 $\mathrm{g} / \mathrm{cm}^{3}$ ). If basaltic magma were now to rise along tensional fissures generated by ocean spreading (Fig. 1A) and (theoretically) were to reach the seafloor $(d=O m)$, its effective hydrostatic pressure $P_{m}$ would be greater than $P_{s}+T$ over a large depth range from the seafloor down to more than 400 meters (Fig. 2B). But this is unrealistic, because long before reaching the sediment surface, the magma, because of its high pressure, would intrude into the sediment. But, if as in Figure 2B, the summit elevation of the magma were to remain $d=200 \mathrm{me}-$ ters sub-bottom, its hydrostatic pressure, enhanced by the effective pressure $P_{s}$ of the overlying sediment at this depth, could not overcome the increased $\left(P_{s}+T\right)$ of the indurated sediment. Hence, below this depth, only vertical dikes, as a consequence of dilational fissures, could be formed. But if magma rises higher than 200 meters sub-bottom, it will form horizontal intrusions. Then the only requirement is that the top of the magma in the vertical conduit be somewhat higher than the level of the intrusions (at least by $\Delta \mathrm{h}$ as in Fig. $2 \mathrm{~B}$ ) to overcome the tensile strength of the sediment.

From this discussion one might conclude that new sills are formed directly above older sills that have solidified and compacted their underlying sediment. But since the sediment above the sills is also indurated to some extent, new sills will intrude on top of these firm or hard sediment layers. Thus, hypothetically, a structure composed of dike-fed sills alternating with sediment is developed (Figs. 1B; 7).

\section{CONSEQUENCES FOR BURIAL DEPTH AND SUCCESSION OF SILLS}

The vertical buildup of an alternating sill-sediment sequence can be slower or faster than the upward growth of the sedimentary surface. If it is slower, an increasing height of soft sediment above the uppermost sill can accumulate and exert a higher lithostatic pressure, and may even start to indurate at a level above the last sill. As a consequence, the next sill intrusion can reach a level considerably higher than the last and therefore, compensate to some extent for the sills that do not vertically build up as rapidly as the growing seafloor. This is apparently occurring in the Guaymas Basin, where the sediment intervals between sills in vertical succession are about 10 to 100 meters (Sites 478 and 481; Fig. 3). Taking into account a sedimentation rate of at least $1 \mathrm{~m} /$ 1000 y. (see site chapters, Site 477 and 481 ), we may conclude that sill intrusions occur in intervals between 10,000 and $100,000 \mathrm{y}$., which reasonably accords with the time interval observed for episodic basalt interruptions at the Mid-Atlantic Ridge (10,000-20,000 y.; Moore et al., 1974). If the buildup of sills is faster than the accumulation rate of sediment, the basaltic magma 


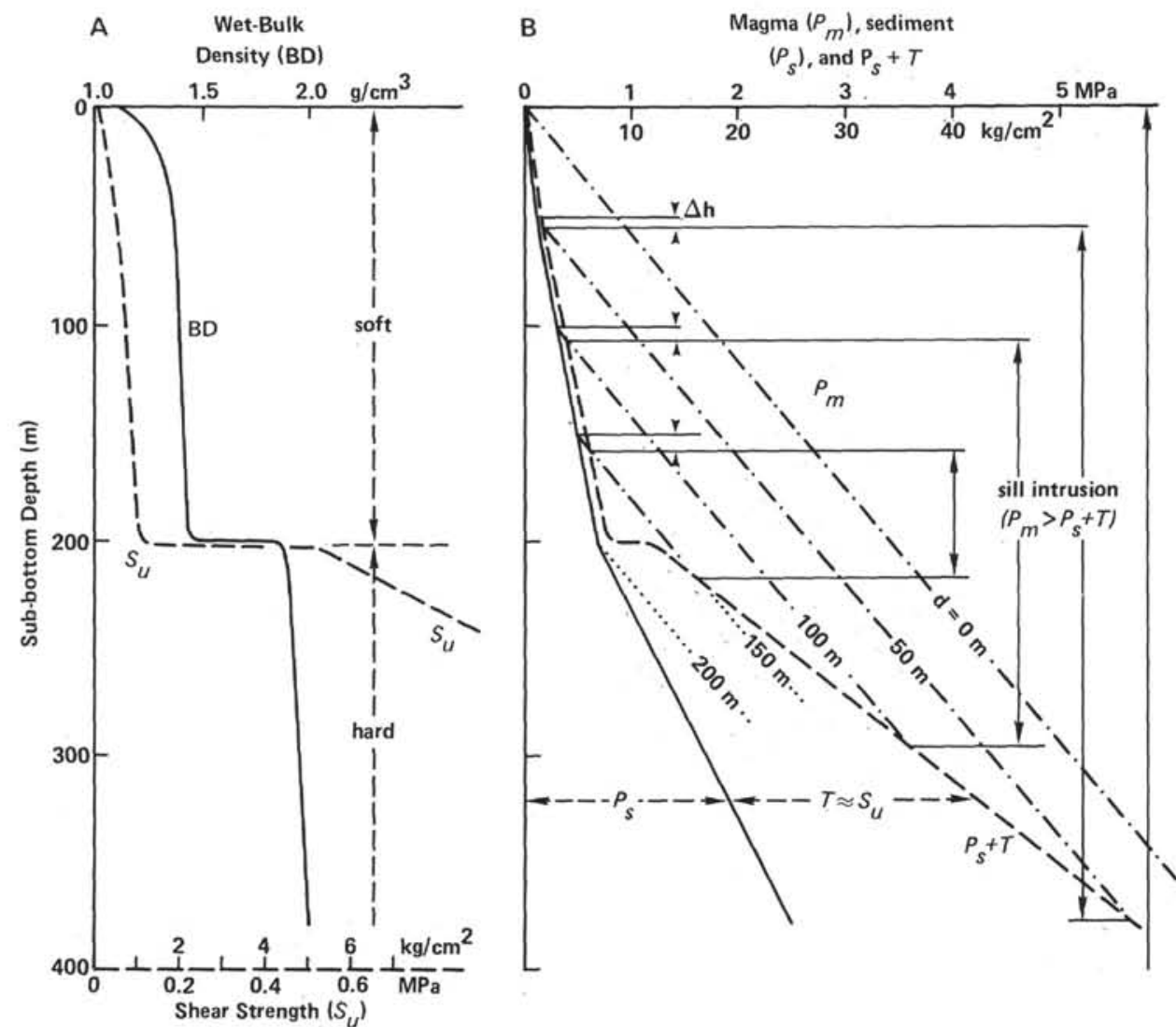

Figure 2. A. Wet-bulk density (BD) and vane shear strength, $S_{u}$ (here regarded equal to tensile strength, $T$ ), plotted versus depth, Guaymas Basin sediment. (For simplification, a sharp change of properties at $200 \mathrm{~m}$ is assumed where sediment becomes hard.). B. Relation between effective overburden pressure, $P_{s}$, of sediment, $P_{s}+T$ (tensile strength of sediment), and magma pressure, $P_{m}$, versus depth. (Magma pressure is plotted for different summit elevations of magma below seafloor $[d=0,50,100$, 150 , and $200 \mathrm{~m}$ ] and is enhanced by the effective pressure, $P_{s}$, of overlying sediments. $\Delta h=$ difference in height between top of magma in feeding conduit and upper limit of possible sill intrusion. Lower limit is determined by $P_{m} \leq P_{s}+T$.)

will soon reach the seafloor and form lava flows. This apparently occurred in the Pliocene at Site 483, Leg 65 in the southern part of the Gulf of California, where sediment accumulated at a rate of about $60 \mathrm{~m} / \mathrm{m}$.y. (Lewis et al., 1979). But in the Quaternary record of Site 485 (Leg 65), with an accumulation rate of about 600 $\mathrm{m} / \mathrm{m}$.y., the massive basalt layers intercalated in sediment probably are sills rather than effusive lava flows. Other implications of crustal growth caused by dikes and sills with contributing sediment will be discussed in Moore and Curray, and Curray, et al., this volume Pt. 2.

In summary, we can conclude that younger sills tend to intrude on top of the contact zones of older sills. Sill intrusions continue as long as sediment accumulation is at least as fast as vertical buildup by sills and their upper contact zones. The burial depth during intrusion is at least as great as the thickness of the contact zone above the sills or the upper limit of petroliferous material expelled from heated sediment (see Simoneit et al., this volume, Pt. 2). When magmatic activity ceases (e.g., by lateral migration of the site away from the active spreading center), only the sediment on top of the sediment-sill complex is deposited.
If we speculate and apply these rules to the drilling results in the Guaymas Basin, we obtain the interpretation shown in Figure 3. The records of the four holes where sills have been encountered are listed according to the sediment thickness overlying the uppermost sill, and we assume that the age of the uppermost sills increases with growing burial depth. This assumption is supported by biostratigraphic evidence (see site chapters) and by the measured heat-flow values, which are highest at Site 477 (about $20 \mathrm{HFU}$ ) and decline to 4 and 2.9 HFU at Sites 481 and 478 , respectively. In other words, whereas the sills in Holes 477 and $477 \mathrm{~A}$ are still hot $\left(50-70^{\circ} \mathrm{C}\right)$, the other sills have had much more time to cool down. In reality, the situation can be more complicated. Heat is transferred not only from cooling sills but also from deeper sources, and intrusion of sills occasionally may also occur some distance from the spreading center proper (Bischoff and Henyey, 1974). The first possibility is indicated by strong gradients of porosity and other physical properties versus depth below the sills at Site 477 (Fig. 3). Therefore, estimating the cooling time of the sill by measuring its present temperature (about $50-70^{\circ} \mathrm{C}$ in Hole 477) and determining the time 


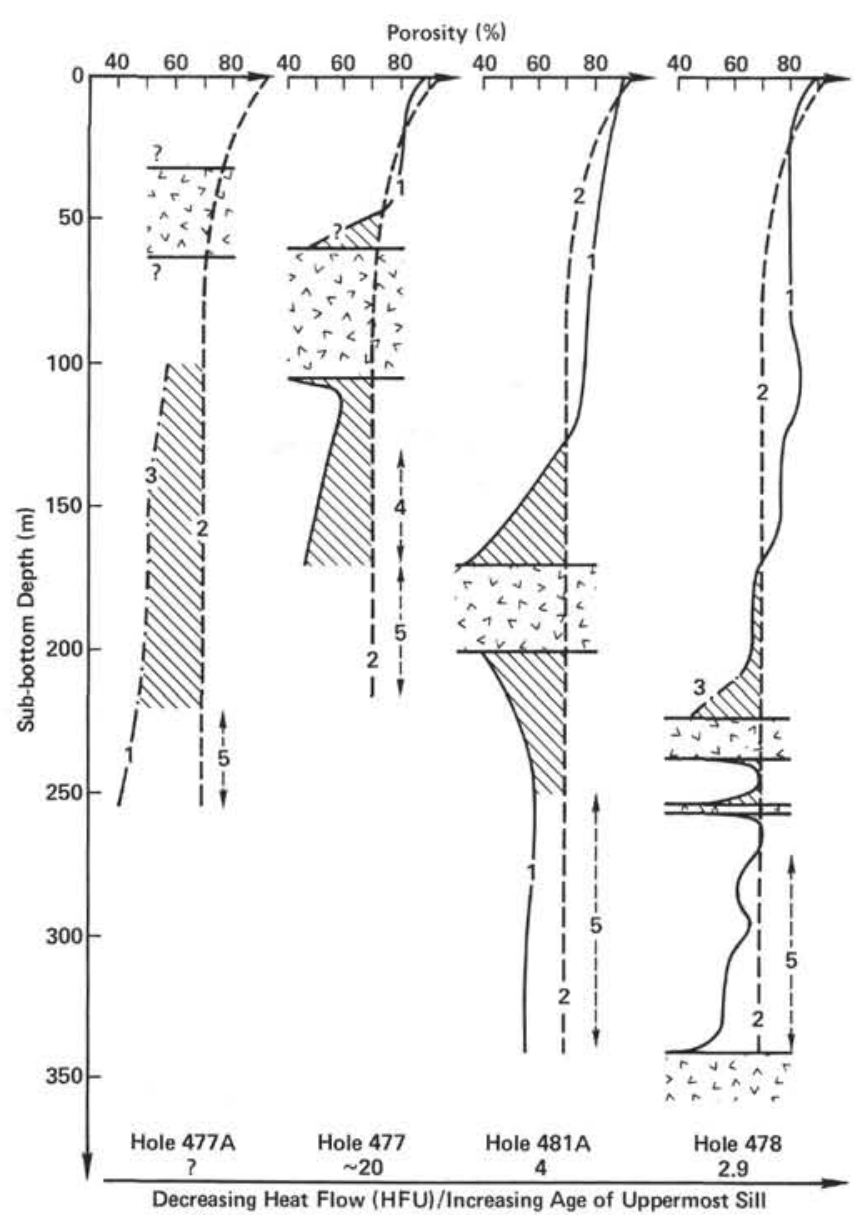

Figure 3. Sill-induced reduction of porosity (hatched areas), Guaymas Basin. $(1=$ shipboard porosity measurement; $2=$ shipboard porosity, Hole 479 [reference line]; 3 = porosity curve deduced from density $\log ; 4=$ porosity reduction caused by deeper intrusions[?]; $5=$ sections not considered for calculation of water loss [Table 1]. Tentatively, the holes are arranged from left to right according to the increasing age of the uppermost sill and decreasing heat flow.)

necessary for the deposition of sediment on top of the upper contact zone (about 20,000 y. in Hole 477) may be, but is not necessarily, erroneous. Heat-flow measurements and seismic records (Lawver et al., 1975) indicate a similar age for the latest basaltic intrusion in the area of Site 477.

\section{CHANGE OF MASS PHYSICAL PROPERTIES AT SILL CONTACT}

Horizontally intruded basaltic sills affect the mass physical properties of the neighboring sediment in several different ways:

1) Unlike the porous sediment, the basaltic magma or its solidified rocks have a very high density and are therefore a substantial additional load on the underlying sediment. As a result, water content and porosity below the sill are markedly reduced (Fig. 3), and bulk density of the sediment increases. At Site 477, where a thick sill is intercalated at shallow depth, the effective pressure $\left(1.02 \mathrm{MPa}=10.2 \mathrm{~kg} / \mathrm{cm}^{2}\right)$ immediately below the sill at 105 meters sub-bottom is the same as at Site 479 at about 300 meters (Fig. 4); however, this change of mass physical properties often cannot be explained by additional loading alone (see also Einsele chapter on mass physical properties, this volume, Pt. 2). For example, at Site 477 the porosity of the sediment below the sill is much lower than that of sediment at Site 479 at 300 meters. The Site 479 sediment, as we have seen, has been subjected to the same effective vertical stress. For that reason and because the sediment on top of the sills is also considerably affected, we must consider heat transfer as a second influence on mass physical properties.

2) Heated pore water in the surroundings of intruding magma can substantially accelerate the dissolution and reprecipitation of certain sediment components (see also the relevant chapters in this volume). Of particular interest is opaline silica, which can be dissolved in quantities of more than $1000 \mathrm{ppm}$ when the temperature is raised above $200^{\circ} \mathrm{C}$ (e.g., Fournier and Rowe, 1966). Actually, the concentration of dissolved silica in interstitial water above and below the sills (as determined on shipboard; see Gieskes, this volume, Pt. 2) was not very high (about $100 \mathrm{ppm}$ at Site 477). But the sills were al-

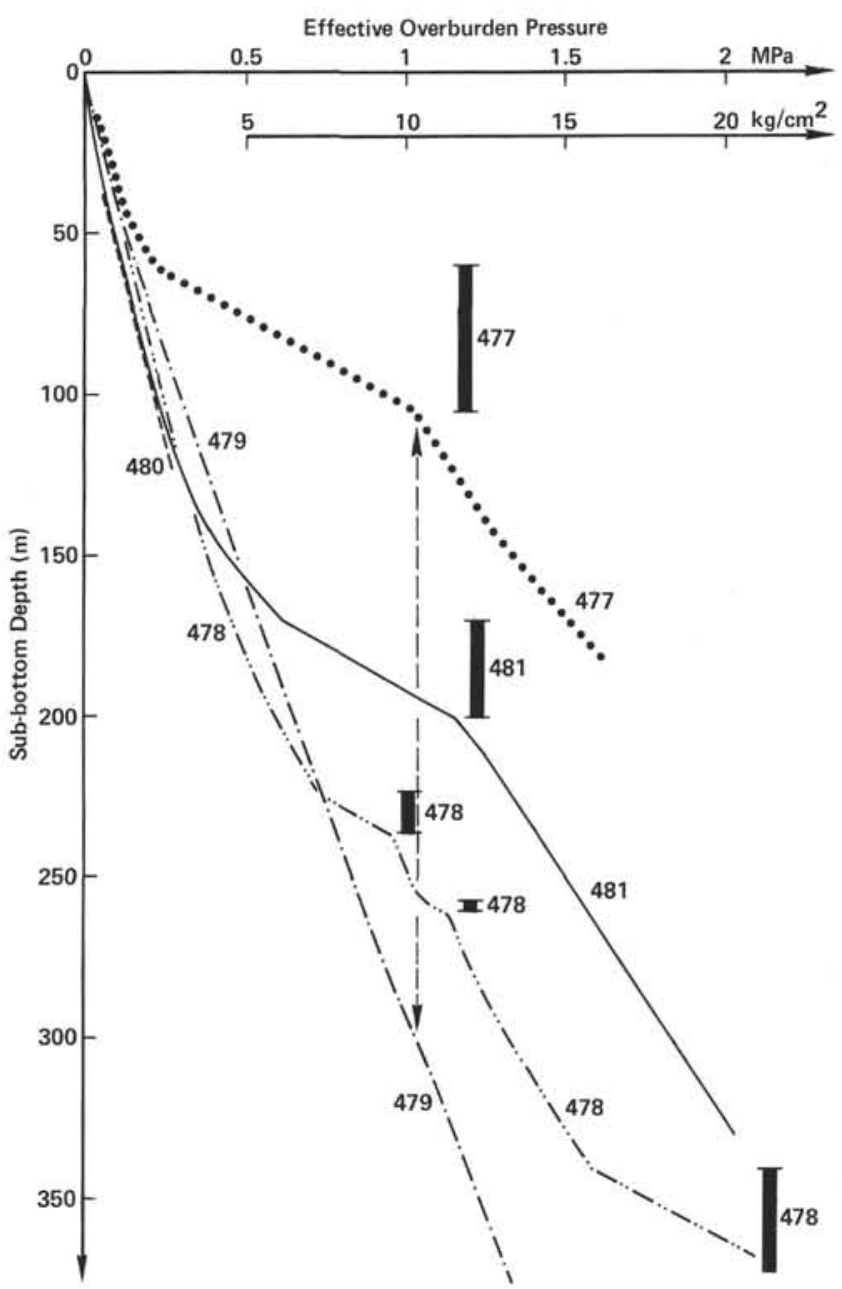

Figure 4. Effective overburden pressure of sediment versus depth, Guaymas Basin. (Note the strong gradients in holes with intercalated sills marked by vertical black bars.) 
ready in a state of long cooling, and much of the primarily dissolved silica had been used up to form new minerals (authigenic quartz, clay minerals, and so forth). In any case, the diatoms, radiolarians, and spicules of sponges have vanished from the sediment near sills (Site 481). Delicate skeletons of carbonate also tend to be preferentially dissolved if the sediment and its pore water are heated. This may explain the complete lack of calcareous nannofossils and, possibly, of foraminifers in a 7-meter-thick zone directly above the uppermost sill at Site 481. At least part of the dissolved carbonate is reprecipitated as cement in some coarser-grained layers. Alteration of sediment and its mass physical properties by heated pore water appears to affect zones that are about two times thicker above than below the sills. At Site 481 , the uppermost, 30 -meter-thick sill has strongly affected a sediment sequence up to 40 meters above but only 20 meters below. ${ }^{3}$ This finding can be explained as a consequence of compaction flow but possibly also of steam action. The upstreaming pore water transfers heat and tends to enlarge the zone of alteration on top of the sill.

3) During and immediately after a sill intrusion, the pore water near thick sills could have been transformed to steam. The critical point for pure $3.5 \%$ sodium chloride solution is 304 bars and $408^{\circ} \mathrm{C}$. Because the sills in the Guaymas Basin have intruded at depths near 2200 meters below sea level, pressures occurred below the critical point. It is difficult to evaluate the effect of such a steam zone on the physical properties (as well as other characteristics) of the sediment. Since the steam pressure can be higher than the hydrostatic pressure of the pore water, in the initial stage it will tend to drive pore water from the neighborhood of the sill. As a result, the sediment will probably shrink and reach porosities similar to those obtained by artificial shrinkage in the laboratory (see Einsele chapter on mass physical properties, this volume, Pt. 2). For sediment rich in clay, this "residual" porosity is 45 to $55 \%$; diatomaceous ooze may maintain porosities as much as 70 to $80 \%$ after shrinkage, but as we have seen, opaline silica is preferentially dissolved at high temperatures. Thus, the low porosity of 40 to $50 \%$ at some upper and lower sill contacts (Holes 477, 478, 481A; Fig. 3 ) may also be caused by shrinkage and boiling pore water. Shrinkage of sediment occurs in all three directions of space. Although the horizontal component of volumetric shrinkage of layered marine sediment usually is smaller than the vertical shrinkage, we can expect vertical shrinkage cracks or fissures. Actually, some vertical partings with a millimeter-thin, blackened rim occur in sediment several meters above the uppermost sill in Hole 481A. Such fissures probably have provided vents for the steam to escape upward. It is also possible that the excess pressure of the steam has overcome the relatively low effective overburden pressure of the overlying sediment (about $0.2-0.6 \mathrm{MPa}=2-6 \mathrm{~kg} / \mathrm{cm}^{2}$ ) and caused some uplift before the excess pressure dissipated along cracks

\footnotetext{
${ }^{3}$ For further information, see Figure 3 and the density logs in the relevant site chapters, this volume, $\mathrm{Pt} .1$.
}

and faults caused by this mechanism. "Baking" of sediment (see Simoneit et al., 1978; Simoneit et al., this volume, $\mathrm{Pt} .2$ ) also appears to require a steam zone near the sill. This would be a kind of insulator and thus reduce the heat transfer from the sill to the sediment for some (relatively short) time. In this interval, sediment and their organic compounds directly at the sill contact can be affected by very high temperature.

These phenomena are also controlled by the thickness of sills. Large intrusions develop thicker contact zones and, possibly, stronger alterations than thin sills. But an alternating sequence of sediment and sills has undergone several thermal events and may still be affected by an underlying or laterally spaced, active heat source (e.g., at Site 477). Therefore, the effects of more than one event can be superimposed.

\section{EXPULSION OF PORE WATER}

Figure 3 indicates that sill intrusions cause a large decrease in the porosity of neighboring sediment. The same is true for wet-water content, but bulk densities and shear-strength values strongly increase versus sill contacts (see Einsele chapter on mass physical properties, this volume). These changes in physical properties can be understood in terms of expulsion of pore fluids. Therefore, an attempt is made, although our data are not as complete as desirable, to calculate the amount of pore water expelled by the processes already described. Since this calculation cannot be very accurate, a rather simple method is used.

We want to know the amount of expelled pore fluids in terms of the height of the water column, which is obtained from the reduction of porosity in the contact zones. This requires estimating porosities before the emplacement of sill intrusions. For Holes 477, 477A, 478 , and $481 \mathrm{~A}$ it has been assumed that the original porosities were similar to those at Site 479 at the northern end of the Guaymas Basin (see Fig. 3 and site chapter, Site 479, this volume, Pt. 1) at corresponding depths. These sediments have not been affected by intruding magma, and their composition resembles that of the basin sites with sills. If there is a difference, the porosities in the basin sites are higher, because the basin sediments were deposited faster than at Site 479 and, therefore, were probably underconsolidated before the magma intruded. For that reason, the calculated water losses represent minimum values.

The height, $h_{p}$, of expelled pore water can be found by using the formula (see also Hamilton, 1976)

$$
h_{p}=h_{1}-h_{2}=h_{2}\left(\frac{100-n_{2}}{100-n_{1}}\right)-1=f \cdot h_{2},
$$

where $h_{1}$ and $n_{1}$ are the original height and porosity of a certain sediment section, and $h_{2}$ and $n_{2}$ are the present (reduced) height and porosity.

It follows from the formula that $h_{p}$ is not a linear function of the reduction in porosity (Fig. 5). If the porosity were reduced from 80 to $70 \%$, then $h_{p}=0.5 h_{2}-$ that is, if $h_{2}=10$ meters (present height of sediment section), then 5 meters of pore water would have been lost, 


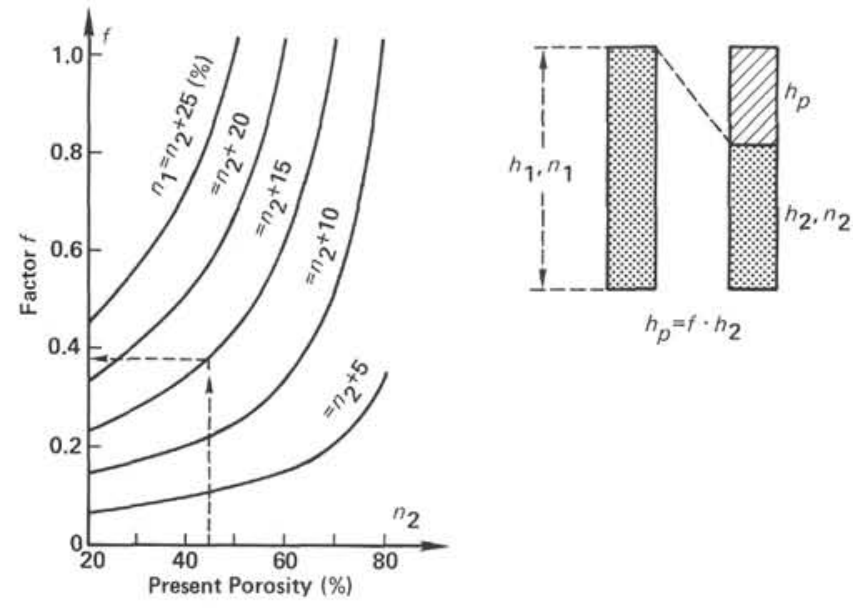

Figure 5. Diagram to determine loss of water, $h_{p}$, from present height, $h_{2}$, of a sediment section if initial and present porosity, $n_{1}$ and $n_{2}$ are known. (If $n_{2}=45 \%$ and $n_{1}=n_{2}+15=60 \%$, then, from the diagram, $f=0.38$. For further explanations see text.)

and the original height of the sediment column would have been 15 meters. If a decrease from 60 to $50 \%$ in porosity were to occur, $h_{p}$ would be only $0.2 h_{2}$ and so on. Using an integrative model, the water loss from the contact zones above and below the uppermost, presumably youngest, sill was calculated (Table 1). The values determined by this method are not very consistent, particularly those for the sediment sections below the uppermost sills. These great hole-to-hole differences in values can be partially explained by the uncertainty whether-and to what extent-these sections have been influenced by older intrusions or processes unrelated to the sill intrusions. Nevertheless, the order of magnitude of the calculated total water loss by single sill intrusions is correct, and it allows us to draw some important conclusions.

\section{Conclusions}

From the results summarized in Table 1, three principal conclusions can be drawn:

1) At all sites, the total water loss of the sediment caused by the uppermost sill is of the same order of magnitude (in height of sediment column) as the thickness of the sill. This suggests that the water removal from the neighboring sediment creates space for the intruding magma, provided that the intrusion is slow, i.e., at about the same rate as expulsion of pore water. A sill intrusion does not then necessarily cause a large change in relief at the seafloor. Seismic records across the young spreading center of the Guaymas Basin show a somewhat more irregular seafloor than most depressions in a seafloor where sediment accumulation is rapid, but they do not show any clear or significant evidence of sediment uplift on top of basaltic intrusions. In older parts of the basin, where these features are buried below younger sediment, the seismic records apparently indicate buried uplift or thinning sediment over isolated intrusive bodies; but this phenomenon may be mainly caused by differential compaction under the overlying sediment. Furthermore, vertically intruding magma can
Table 1. Reduction of porosity and water loss by intrusion of the uppermost sill (cf. Fig. 3).

\begin{tabular}{|c|c|c|c|c|c|}
\hline \multirow[b]{2}{*}{ Hole } & \multicolumn{2}{|c|}{$\begin{array}{l}\text { Thickness of } \\
\text { Sediment Sections } \\
\text { Influenced by } \\
\text { Uppermost Sill }\end{array}$} & \multicolumn{2}{|c|}{$\begin{array}{c}\text { Loss of Water } \\
\text { (as height of } \\
\text { water column) } \\
h_{p}(\mathrm{~m})\end{array}$} & \multirow{2}{*}{$\begin{array}{l}\text { Thickness of } \\
\text { Uppermost Sill } \\
\text { (m) }\end{array}$} \\
\hline & $h_{2}$ & (m) & Sections & Total & \\
\hline \multirow[t]{2}{*}{477} & above sill & (?)13 & 7.3 & & \\
\hline & below sill & $\begin{array}{c}7 \\
69^{\mathrm{a}}\end{array}$ & $\begin{array}{r}3.0 \\
33.4\end{array}$ & ca. 44 & 45 \\
\hline \multirow[t]{2}{*}{$477 \mathrm{~A}$} & above sill & $?$ & $?$ & & \\
\hline & below sill & $\begin{array}{c}35 \\
120^{\mathrm{b}}\end{array}$ & $\stackrel{?}{75.6}$ & $\begin{array}{l}\text { at least } \\
\text { ca. } 75\end{array}$ & 30 \\
\hline 478 & $\begin{array}{l}\text { above sill } \\
\text { below sill }\end{array}$ & $\begin{array}{l}56 \\
12\end{array}$ & $\begin{array}{r}12.3 \\
1.4\end{array}$ & ca. $14^{d}$ & 17 \\
\hline 481 & $\begin{array}{l}\text { above sill } \\
\text { below sill }\end{array}$ & $\begin{array}{l}45 \\
50\end{array}$ & $\begin{array}{l}24.9 \\
28.6\end{array}$ & ca. 53 & 30 \\
\hline
\end{tabular}

Note: For symbols and formulas, see text.

a Part of the porosity decrease of this section may be the result of a deeper hot intrusion. On the other hand, the sediments below those which were drilled are also affected by the load of the uppermost sill.

$\mathrm{b}$ Porosity deduced from density log. The cored section from 220-260 meters with $n_{2}=$ ca. $45 \%$ may be influenced by a deeper sill and is therefore not considered.

${ }^{c}$ Including thin sill at ca. 250 meters. We assume that this sill has intruded simultaneously with the uppermost sill.

$\mathrm{d}$ Minimum value, since real porosity reduction was probably larger than indicated by Reference Line 2 in Fig. 3.

also expel pore water from the sediment walls and create more space for the emplacement of dikes.

2) If a sill of 30 to 40 meters thick were to expel a water column of at least 30 meters (say $15 \mathrm{~m}$ above and below the sill) and if it were to occupy-perhaps with simultaneously intruded neighboring sills along an elongated crustal fissure zone-an area of $1 \mathrm{~km}^{2}$, about $3 \cdot 10^{7} \mathrm{~m}^{3}$ pore fluid would be forced to the seafloor. This water migrates through somewhat tilted beds of relatively good permeability (e.g., the sandy base of turbidites) until it reaches one of the many faults known from seismic records. These act as conduits, leading the heated waters upward (Fig. 6). At some later stage, some of the turbidites may become lithified and form cap rocks. But fissures within these layers or in the cooling sill create sufficient permeability for water to escape laterally. The additional overburden load provided by the sill may, by compaction, still expel pore water from the underlying sediment when the sill has cooled and the process on top of the sill has ceased. Sediment precompacted by the intrusion of older, deeper sills probably is only slightly affected by the younger intrusions.

3) The huge amounts of pore water expelled from sediment escape along faults to the seafloor where they react with seawater and precipitate part of their dissolved constituents as a special sort of hydrothermal deposit (see Einsele et al., 1980 and relevant chapters, this volume). The discharge and duration of these submarine hot springs depend very much on the cooling time of the magmatic intrusions. One can expect that the discharge and temperature of the springs are high immediately after an intrusion, and that they decline in the course of cooling and with prograding adjustment 


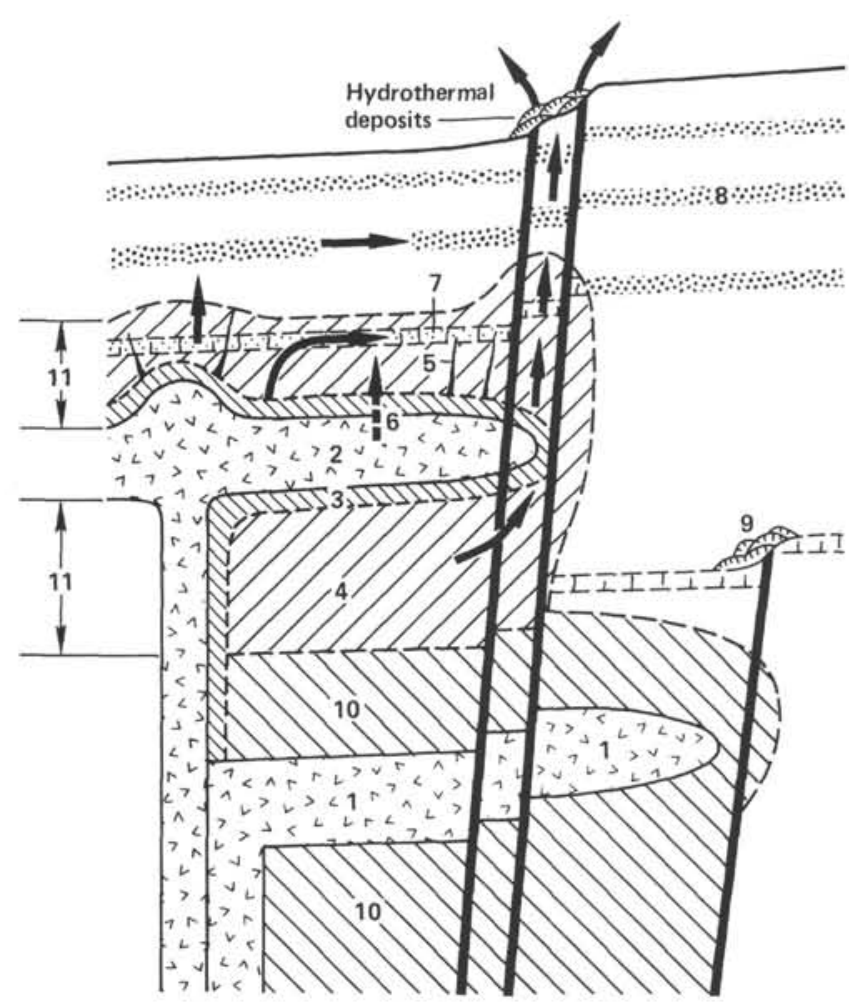

Figure 6. Model of water expulsion from sediment and the onset of a hydrothermal system as a result of intruding sills. $(1=$ older lower sill; 2 = young uppermost sill; 3 = possible steam zone, at inner sill contact baked sediments; 4 = zone of sill-reduced porosity; $5=$ shrinkage cracks acting as vents for escaping steam; $6=$ possible transfer of dissolved chemical species from magma to sediment; $7=$ permeable layer lithified during pore water flow [arrows]; $8=$ nonindurated sandy base of mud turbidites; $9=$ buried older hydrothermal deposits; $10=$ precompacted by older sill; $11=$ zones of water loss).

of sediment to additional loading. Thus, the nature and volume of hydrothermal deposits per time unit are also subject to considerable changes. In any case, the volume of sill-expelled pore water would be sufficient to feed a discharge of $10 \mathrm{l} / \mathrm{s}$. from an area of $1 \mathrm{~km}^{2}$ for a period of $100 \mathrm{y}$.

\section{STRUCTURAL RELATION BETWEEN SEDIMENTS AND BASALTS AT A GULF-TYPE SPREADING CENTER}

Finally, a first attempt is made to interpret the findings in the Guaymas Basin in terms of the structural evolution of a gulf-type spreading center (Fig. 7). The principal problem is how to fill the "gap" developing between the drifting blocks at the spreading center (see also Moore, 1973). Since spreading takes place at a rate 30 to 60 times faster than sediment accumulation, the gap must be filled chiefly by magma in the form of vertical dikes. At the spreading trough, a few hundred meters (at most) of sediment can be deposited before this section migrates laterally and is buried by younger sediment beside a newly formed trough. Magmatic pulses with exceptionally high pressure heads raise magma high enough to develop dikes and sills within the trough sediment and sometimes also within the sediment at the basinal flanks. Occasionally, magma extrudes at the seafloor to build up submarine knolls. Spreading and magmatic pulses are accompanied by faulting that is chiefly parallel to the spreading axis (growth faults). Such faults are used by the sill-expelled pore water to migrate to the seafloor, where hydrothermal deposits may be precipitated. The growth of the entire structure chiefly takes place laterally. Thus, stratigraphic relations are to be expected in a succession as indicated in Figure 7. With increasing distance from the spreading center, the ocean crust-including the "Mixed Layer" B (Fig. 7) -tends to subside. But this subsidence is more than compensated by sediment accumulation at the flanks of the central trough. Thus, the basinal morphology of the spreading center is maintained as long as the vertical upbuilding by sediment exceeds that of basaltic sills. An earlier discussion of this problem was presented by Moore (1973).

\section{ACKNOWLEDGMENTS}

This study has greatly benefitted from the cooperation of the Leg 64 scientific and technical teams aboard Glomar Challenger. Especially helpful were discussions with the Leg 64 co-chief scientists, J. R. Curray and D. G. Moore, as well as with J. M. Gieskes, M. Kastner, and K. Kelts. W. Frisch (Vienna) and E. L. Hamilton (San Diego) critically read the manuscript and made valuable suggestions. Financial support was provided by the German Research Foundation.

\section{REFERENCES}

Bischoff, J. L., and Henyey, T. L., 1974. Tectonic elements of the central part of the Gulf of California. Geol. Soc. Am. Bull., 85:18931904.

Bradley, J., 1965. Intrusion of major dolerite sills. Trans. Roy. Soc. N. Z., 3:27-55.

Einsele, G., Gieskes, J. M., Curray, J., et al., 1980. Intrusion of basaltic sills into highly porous sediments, and resulting hydrothermal activity. Nature, 283:441-445.

Fisher, R. L., Bunce, E. T., et al., 1974. Init. Repts. DSDP, 24: Washington (U.S. Govt. Printing Office).

Fournier, R. O., and Rowe, J. J., 1966. Estimation of underground temperature from the silica content of water from test springs and steam wells. Am. J. Sci., 264:685-697.

Frankel, J. J., 1967. Intrusive basaltic rocks. In Hess, H. H., and Poldervaart, A. (Eds.), Basalts (Vol. 1): New York (John Wiley), 86102.

Grapes, R. H., Reid, D. L., and McPherson, J. G., 1974. Shallow dolerite intrusion and phreatic eruption in the Allan Hills region, Antarctica. J. Geol. Geophys. N. Z., 17:563-577.

Hamilton, E. L., 1976. Variations of density and porosity with depth in deep-sea sediments. J. Sediment. Petrol., 46:280-300.

Lawver, L. A., Williams, D. L., and Von Herzen, R. P., 1975. A major geothermal anomaly in the Gulf of California. Nature, 257:23-28.

Lewis, B. T. R., Robinson, P., Benson, N., et al., 1979. Leg 65 drills into young ocean crust. Geotimes, 24:16-18.

Moore, D. G., 1973. Plate-edge deformation and crustal growth, Gulf of California structural province. Geol. Soc. Am. Bull., 84:18831906.

Moore, J. G., Fleming, H. S., and Phillips, J. D., 1974. Preliminary model for extrusion and rifting at the axis of the Mid-Atlantic Ridge, $36^{\circ} 48^{\prime}$ north. Geology, 2:437-440.

Roberts, J. L., 1970. The intrusion of magma into brittle rocks. In Newall, G., and Rast, N. (Eds.), Mechanism of Igneous Intrusion: Geol. J. Spec. Issue, 2:287-338. 
Sauvan, P., Esquevin, J., and Chennaux, G., 1975. Transformations induites par des intrusions doléritiques dans une série argileuse: L'Ecca de' Bergville (Afrique du Sud). Bull. Cent. Rech. Pau, 9: 261-351.

Sclater, J. G., Anderson, R. W., and Bell, M. L., 1971. Elevation of ridges and evolution of the central eastern Pacific. J. Geophys. Res., 76:7888-7915.
Simoneit, B. R. T., Brenner, S., Peters, K. E., et al., 1978. Thermal alteration of Cretaceous black shale by basaltic intrusions in the Eastern Atlantic. Nature, 273:501-504.

Whitmarsh, R. B., Weser, O. E., Ross, D. A., et al., 1974. Init. Repts. DSDP, 23: Washington (U.S. Govt. Printing Office).

Williams, H., and McBirney, A. R., 1979. Volcanology: San Francisco (Freeman \& Cooper).

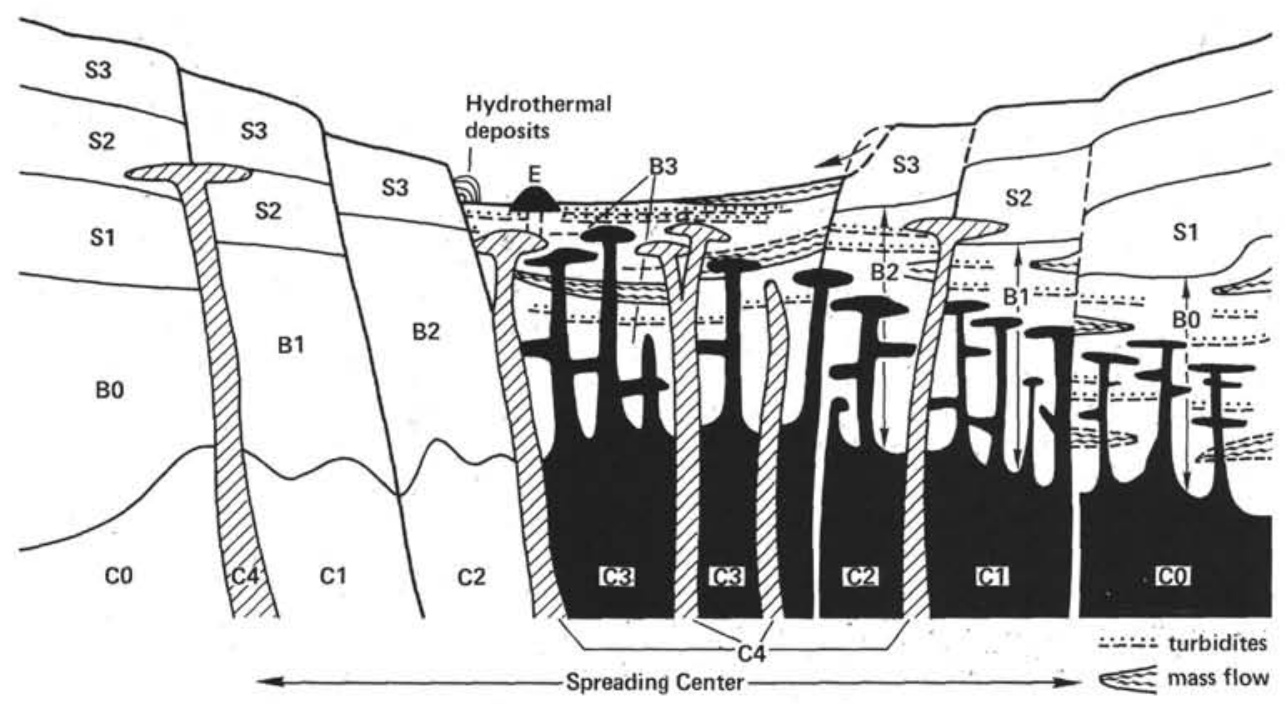

Figure 7. Hypothetical section across gulf-type spreading center (3-4 km wide) with central trough 2000 to 3000 meters below sea level. C. Top of oceanic crust chiefly built up by dikes. E. Occasional eruptions on the sea floor. B. Dikes, sills, and sediment altered by basaltic intrusions. S. Sediment containing many mud turbidites and mass flow deposits. (Numbers signify succession of events. New intrusions [C4] are not limited to the spreading center, expelled pore water forms hydrothermal deposits along growth faults. Vertical scale several times exaggerated.) 